JIPVA (JURNAL PENDIDIKAN IPA VETERAN)

Volume 3 - Nomor 1, 2019

Available at http://e-journal.ivet.ac.id/index.php/jipva

ISSN : 2598-5876 (print), 2598-0904 (online)

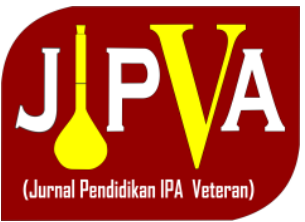

\title{
Model problem based learning berbantuan jurnal belajar terhadap kemampuan metakognitif siswa
}

\author{
Puji Lestari ${ }^{1}$, Sri Wardani ${ }^{2}$, Miranita Khusniati ${ }^{3 *}$ \\ Jurusan IPA Terpadu ${ }^{1,3}$, Fakultas Matematika dan Ilmu Pengetahuan Alam, Universitas Negeri \\ Semarang, Semarang, Jawa Tengah, Indonesia \\ Jurusan Kimia $^{2}$, Fakultas Matematika dan Ilmu Pengetahuan Alam, Universitas Negeri \\ Semarang, Semarang, Jawa Tengah, Indonesia \\ *Coressponding author email: miranita@mail.unnes.ac.id
}

\begin{tabular}{ll} 
Artikel info \\
\hline Received : 18 Februari 2019 \\
Revised $: 11$ April 2019 \\
Accepted $: 18$ April 2019
\end{tabular}

Kata kunci:

Hasil belajar kognitif

Jurnal belajar

Kemampuan metakognitif PBL

\begin{abstract}
ABSTRAK
Jurnal belajar dapat dijadikan sebagai media untuk melakukan kegiatan menilai diri sendiri yang dapat dintegrasikan dengan problem-based learning (PBL). Tujuan dari penelitian ini adalah untuk mengetahui pengaruh model PBL berbantuan jurnal belajar terhadap hasil belajar kognitif dan kemampuan metakognitif siswa. Desain penelitian ini yaitu quasi-experimental design dengan bentuk posttest-only control design. Hasil penelitian menunjukkan bahwa pengaruh model PBL berbantuan jurnal belajar terhadap hasil belajar kognitif sebesar $61 \%$ dengan kategori kuat, sedangkan pengaruh model PBL berbantuan jurnal belajar terhadap kemampuan metakognitif sebesar $41 \%$ dengan kategori sedang. Berdasarkan analisis data untuk belajar kognitif siswa menunjukkan bahwa model PBL berbantuan jurnal belajar berpengaruh secara signifikan terhadap hasil belajar kognitif siswa. Hasil uji t menunjukkan bahwa jurnal belajar memberikan pengaruh yang sedang terhadap kemampuan metakognitif siswa. Oleh karena itu, disimpulkan bahwa pembelajaran menggunakan model PBL berbantuan jurnal belajar berpengaruh terhadap hasil belajar kognitif dan kemampuan metakognitif siswa.
\end{abstract}

ABSTRACT

Keywords:

Cognitive learning outcome

Learning journal

Metacognitive skill

$P B L$

\begin{abstract}
Problem based learning model with learning journal towards student metacognitive skills. Learning journals can be used as a medium to carry out self-assessment activities, which can be integrated with problem-based learning (PBL). The purpose of this study was to determine the effect of $P B L$ models assisted by learning journals on cognitive learning outcomes and students' metacognitive abilities. The design of this study is quasiexperimental design with the form of posttest-only control design. The results showed that the effect of the PBL model assisted by learning journals on cognitive learning outcomes was $61 \%$ with a strong category, while the effect of the PBL model assisted by learning journals on metacognitive abilities was $41 \%$ with the medium category. Based on data analysis for cognitive learning of students shows that the PBL model assisted by learning journals significantly influences students' cognitive learning outcomes. The results of the t-test indicating that learning journal has a moderate influence on students' metacognitive abilities. Thus, it can be concluded that learning using the PBL model assisted by learning journals affect the cognitive learning outcomes and metacognitive abilities of students.
\end{abstract}

https://doi.org/10.31331/jipva.v3i1.797

How to Cite: Lestari, P., Wardani, S., \& Khusniati, M. (2019). Model problem based learning berbantuan jurnal belajar terhadap kemampuan metakognitif siswa. JIPVA (Jurnal Pendidikan IPA Veteran), 3(1), 37-50. doi: https://doi.org/10.31331/jipva.v3i1.797

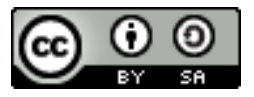




\section{PENDAHULUAN}

Belajar merupakan suatu proses penting yang berkaitan dengan perubahan perilaku seseorang sebagai akibat dari pengalaman (Black \& Schwartz, 2015; White, 2011). Belajar memegang peranan dalam perkembangan, kebiasaan, sikap, keyakinan, tujuan, kepribadian, dan persepsi seseorang (Rifa'i \& Anni, 2012). Proses pembelajaran yang baik akan meningkatkan mutu pendidikan. Mutu pendidikan memiliki pengaruh terhadap perkembangan dan kemajuan suatu negara (Masino \& Niño-Zarazúa, 2016; Skinner, Blum, \& Bourn, 2013). Sebagaimana yang termaktup dalam UU No. 20 tahun 2003, bahwa pendidikan nasional berfungsi mengembangkan kemampuan dan membentuk watak serta peradaban bangsa. Salah satu mata pelajaran yang disisipkan pada kurikulum di sekolah menengah sebagai substansi penting dalam pembelajaran adalah mata pelajaran Ilmu Pengetahuan Alam (IPA).

IPA mempelajari gejala-gejala alam dengan berlandaskan pada serangkaian penelitian untuk mencari jawaban atas alasan terjadinya gejala-gejala tersebut (Kissin, 2013; Rahayu, Mulyani, \& Miswadi, 2012). Gejala-gejala alam yang terjadi dibuktikan dengan metode ilmiah (Khusniati, 2014). Lebih lanjut, Trianto (2010), menyatakan bahwa hakikat IPA memiliki empat unsur utama, yaitu (1), sikap: rasa ingin tahu tentang benda, fenomena alam, makhluk hidup, serta hubungan sebab akibat yang menimbulkan masalah baru yang dapat dipecahkan melalui prosedur yang benar; (2), proses: prosedur pemecahan masalah didasarkan pada metode ilmiah; (3), produk: berupa fakta prinsip, teori dan hukum; dan (4), aplikasi: penerapan metode ilmiah dan konsep IPA dalam kehidupan sehari-hari.

Hasil observasi lapangan dan wawancara dengan guru IPA di SMPN 4 Jatiyoso Kabupaten Karanganyar, Jawa Tengah menunjukkan bahwa pembelajaran IPA yang dilakukan belum memunculkan keempat unsur hakikat IPA. Siswa lebih disajikan IPA sebagai produk dengan menghafalkan konsep, teori, dan, hukum yang kemudian penilaian hasil belajarnya berorientasi pada tes/ujian. Sehingga, tidak heran ketika ditemukan kemampuan kognitif siswa di sekolah tersebut masih rendah. Sebanyak 37 siswa dari 80 Siswa kelas VIII belum lulus Kriteria Ketuntasan Minimal (KKM) untuk mata pelajaran IPA atau sekitar 46,25 \% dengan KKM 74. Selain kemampuan kognitif siswa, kemampuan metakognitif siswa juga belum berkembang dengan baik. Menurut Widadah, Afifah, dan Suroto (2013) aktivitas merencanakan penyelesaian tugas, memonitor pemahaman, dan mengevaluasi perkembangan kognitif merupakan aspek metakognitif yang terjadi dalam sehari-hari. Namun, hal ini belum terlihat pada sebagian besar siswa. Mereka teramati hanya melakukan aktivitas belajar saat ada pekerjaan rumah ataupun ujian. Tidak hanya itu, siswa juga terlihat sering mencontek pekerjaan temannya saat mengerjakan soal.

Kemampuan metakognitif yang belum berkembang dapat dipengaruhi oleh cara evaluasi. Penilaian berperan penting pada pembelajaran IPA agar guru mengetahui kemampuan siswa sehingga dapat dilakukan tindak lanjut yang tepat untuk siswa (Iskandar, 2014; Kallio, Virta, \& Kallio, 2018; Nurwahidah, 2017; Panchu, Bahuleyan, Seethalakshmi, $\&$ Thomas, 2016). Penilaian yang baik adalah penilaian yang menekankan pada proses yang terjadi (Fauziya \& Suhara, 2015). Sudarmin, (2015) menyatakan bahwa pelaksanaan penilaian pada pembelajaran IPA terpadu harus dilakukan dengan menilai proses dan hasil pembelajaran siswa. Permasalahan yang terjadi di sekolah adalah penilaian lebih menekankan pada hasil akhir. Hal tersebut mengakibatkan guru tidak mampu memonitoring dan 
mengevaluasi setiap tahap perkembangan belajar siswa secara menyeluruh. Siswa hanya mengetahui hasil belajar dan menjadi tidak memahami sejauh mana kemampuannya.

Keterampilan seseorang dalam melakukan refleksi diri dapat mendorong perkembangan kognitif, metakognitif, meningkatnya daya pikir, perilaku belajar, dan hasil belajar siswa (Setiawan \& Susilo, 2015; Herlianti, Linuwih, \& Dwijananti, 2015). Ketrampilan berpikir siswa perlu dikembangkan agar siswa memiliki kemampuan HOT (Nurwahidah, 2018). Kemampuan metakognitif dapat dikembangkan salah satunya dengan menerapkan kegiatan menulis jurnal belajar. Jurnal belajar dapat dijadikan sebagai media untuk melakukan kegiatan menilai diri sendiri. Menurut Widiyawati (2017) kurangnya ketersediaan media pembelajaran IPA yang inovatif membuat pembelajaran kurang menarik bagi siswa. Kegiatan refleksi dalam pembelajaran dapat meningkatkan kemampuan seseorang untuk menganalisis kelebihan dan kekurangan diri sendiri (Khusniati, 2012). Manfaat yang diperoleh dari kegiatan menulis jurnal belajar adalah mendorong siswa menyadari apa yang mereka alami (Siberman, 2014). Sejalan dengan Siberman, Lwin et al. (2008) menambahkan manfaat lain yang diperoleh dari kegiatan menulis jurnal, yaitu seseorang mampu melakukan eksplorasi lebih banyak mengenai siapa dirinya. Penerapan jurnal belajar akan lebih baik jika diterapkan dalam pembelajaran yang aktif dan menyenangkan.

Pembelajaran yang menyenangkan adalah suasana pembelajaran dimana siswa secara aktif melakukan serangkaian kegiatan. Salah satu kegiatan yang dapat diterapkan untuk mengasah kemampuan kognitif dan metakognitif siswa adalah dengan diberikan tugas pemecahan masalah (Putri \& Kurniati, 2015). Pada kegiatan ini, siswa diarahkan untuk mengembangkan kemampuannya dalam membangun pengetahuan yang baru, dapat memecahkan masalah dalam berbagai konteks yang berkaitan dengan kehidupan sehari-hari, menerapkan berbagai strategi yang diperlukan, dan merefleksikan proses pemecahan masalah. Pendekatan ini digunakan karena dalam membelajarkan IPA, siswa harus dilibatkan pada masalah yang ada di kehidupan sehari-hari. Tujuannya agar siswa memiliki beberapa kompetensi, yaitu meneliti, mengemukakan pendapat, menerapkan pengetahuan sebelumnya, dan memunculkan ide-ide (Huda, 2013). Model pembelajaran yang dapat digunakan adalah model PBL. Susilo (2012) menyatakan bahwa tujuan utama PBL adalah untuk meningkatkan penerapan pengetahuan, kemandirian, pemecahan masalah, dan meningkatkan kemampuan berpikir kritis. Dengan demikian, siswa lebih aktif selama mengikuti proses pembelajaran.

Peran aktif siswa dalam pembelajaran diharapkan mampu meningkatkan keterampilan siswa dalam memaknai hakikat tentang pentingnya belajar (Walker \& Shore, 2015; Zosh et al., 2017). Peran aktif siswa tidak hanya ditekankan pada saat proses pembelajaran, tetapi juga aktif dalam melakukan refleksi diri melalui kegiatan menulis jurnal belajar (Triana, 2012; Wahdah, Jufri, \& Zulkifli, 2016). Kegiatan belajar yang aktif dengan menggunakan model PBL menuntun siswa untuk menyelesaikan masalah dengan benar berlandaskan pengetahuan ilmiah. Hal ini sejalan dengan Dunlap (2006) bahwa penulisan jurnal belajar yang dipadu dengan model PBL dapat mengembangkan kemampuan metakognitif. Mengacu pada berbagai uraian tersebut, maka penelitian amat penting untuk dilakukan. Tujuan dari penelitian ini adalah untuk mengetahui pengaruh model PBL berbantuan jurnal belajar terhadap hasil belajar kognitif dan kemampuan metakognitif siswa. 


\section{METODE}

\section{Jenis Penelitian}

Penelitian ini merupakan penelitian Quasi Experimental Design. Desain yang digunakan adalah Posttest-Only Control Design.

Tabel 1. Posttest-only control design

\begin{tabular}{ccc}
\hline Kelas & Perlakuan & Posttest \\
\hline $\mathrm{R}$ & $\mathrm{X}$ & $\mathrm{O}_{1}$ \\
$\mathrm{R}$ & & $\mathrm{O}_{2}$ \\
\hline
\end{tabular}

Keterangan:

$\mathrm{O}_{1}=$ Posttest kelas eksperimen

$\mathrm{O}_{2}=$ Posttest kelas kontrol

$\mathrm{X}=$ Pembelajaran mengunakan jurnal belajar dalam PBL

\section{Waktu dan Tempat Penelitian}

Penelitian dilakukan di SMPN 4 Jatiyoso Kabupaten Karanganyar, Jawa Tengah pada tahun ajaran 2017/2018. Populasi penelitian yaitu seluruh siswa kelas VII SMPN 4 Jatiyoso tahun ajaran 2017/2018.

\section{Target/Subjek Penelitian}

Sampel ditentukan dengan teknik purposive sampling. Jumlah sampel yang digunakan adalah dua kelas yang bersifat homogen. Uji homogenitas dan normalitas data awal menggunakan nilai UN yang digunakan untuk mendaftar ke SMPN 4 Jatiyoso. Masingmasing kelas terdiri atas 22 dan 21 siswa. Kelas VIIA sebagai kelas eksperimen dengan perlakuan menulis jurnal belajar dalam model PBL. Kelas kontrol yaitu VIIB menggunakan ceramah dan diskusi sesuai buku siswa.

Variabel bebas dalam penelitian ini adalah jurnal belajar dalam model PBL. Variabel terikat dalam penelitian ini yaitu hasil belajar kognitif dan kemampuan metakognitif siswa. Variabel kontrol dalam penelitian ini meliputi guru, materi dan jumlah jam pembelajaran. Kegiatan penelitian yang dilaksanakan terdiri atas tiga tahap yaitu observasi dengan wawancara untuk mengetahui kemampuan awal siswa kelas VIIA dan kelas VIIB. Tahap berikutnya adalah pembelajaran melalui penerapan jurnal belajar dalam model PBL (Setiawan \& Susilo, 2015). Tahap terakhir yaitu kegiatan posttest untuk mengukur hasil belajar kognitif dan kemampuan metakognitif akhir siswa kelas VIIA dan VIIB. Hasil belajar kognitif diukur menggunakan soal pilihan ganda sedangkan kemampuan metakognitif diukur dengan soal uraian.

\section{Prosedur}

Metode pengambilan data yang digunakan pada penelitian ini yaitu metode tes, observasi dan dokumentasi. Instrumen penelitian yang digunakan ada dua, yaitu tes dan nontes. Soal tes yang digunakan untuk mengukur hasil belajar kognitif adalah soal pilihan ganda yang disusun berdasarkan taksonomi Bloom. Tes yang sudah disusun diukur validitas, reliabilitas, daya beda, dan tingkat kesukarannya sebelum digunakan untuk posttest pada 
penelitian yang dilaksanakan. Sedangkan soal tes yang digunakan untuk mengukur kemampuan metakognitif siswa adalah soal uraian yang disusun berdasarkan aspek-aspek kemampuan metakognitif menurut (Widadah et al., 2013).

\section{Data, Intrumen, dan Teknik Pengumpulan Data}

Analisis data yang dilakukan diantaranya uji normalitas data nilai akhir. Analisis hasil belajar kognitif dan kemampuan metakognitif menggunakan data nilai tes. Hasil belajar kognitif dan kemampuan metakognitif dianalisis menggunakan korelasi biserial.

\section{HASIL DAN PEMBAHASAN}

Penelitian ini dilakukan untuk mengetahui pengaruh model PBL berbantuan jurnal belajar terhadap kemampuan metakognitif siswa. Model pembelajaran PBL diterapkan di kelas pada materi objek IPA dan pengamatannya dengan berbantuan jurnal belajar. Tugas membuat jurnal belajar dibuat oleh siswa pada setiap akhir pertemuan. Contoh jurnal belajar yang dibuat oleh siswa dapat dilihat pada Gambar 1.

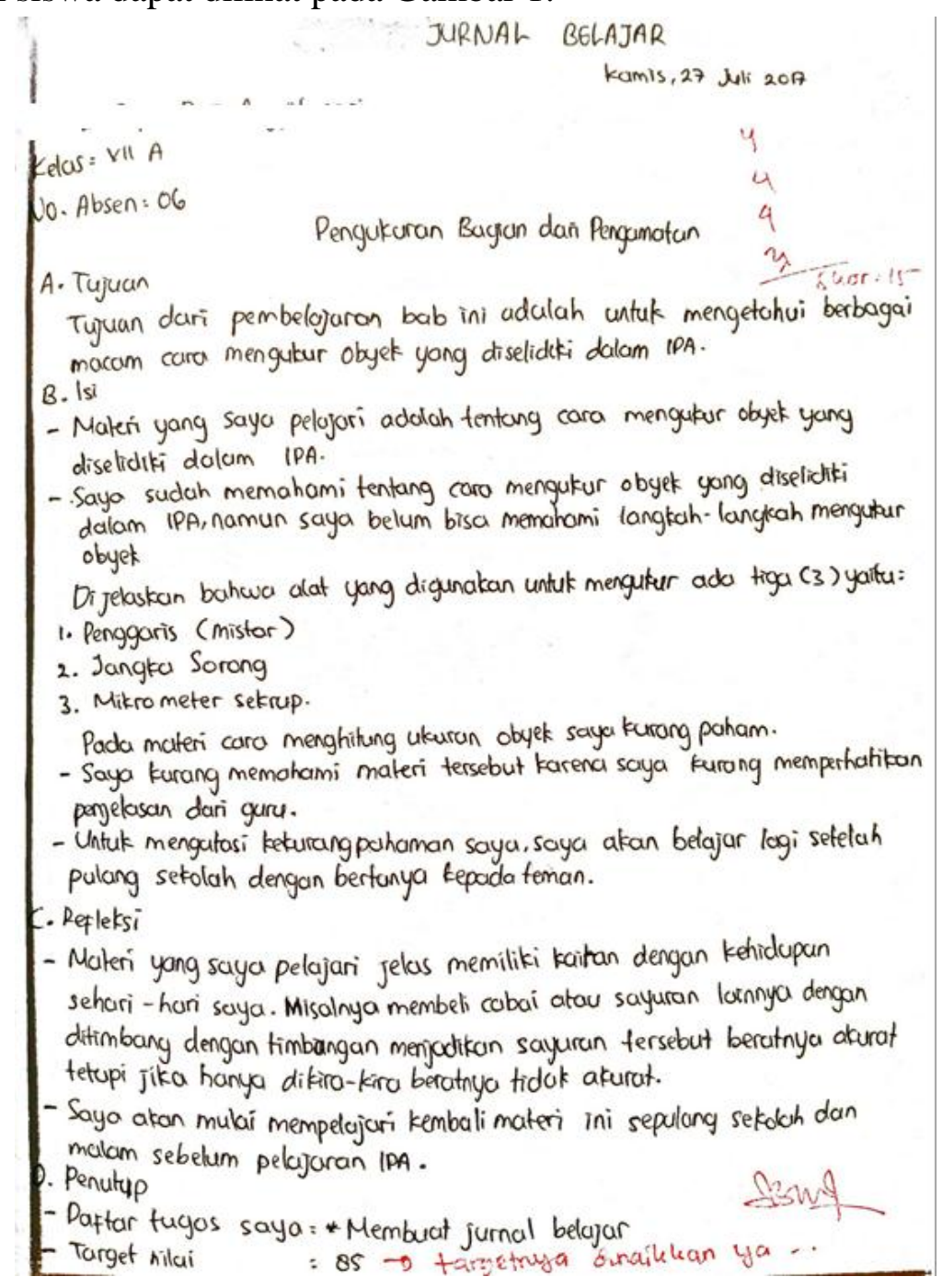

Gambar 1. Contoh jurnal belajar siswa

Gambar 1 menunjukkan hasil jurnal belajar siswa pada satu pertemuan. Jurnal belajar siswa terdiri dari judul, tujuan pembelajaran, isi materi yang sedang dipelajari, refleksi, dan 
penutup. Pada refleksi siswa menuliskan kelebihan dan kekurangannya sehingga guru dapat mengetahuinya secara akurat. Dengan mengetahui kelebihan dan kekurangan yang dirasakan siswa, guru dapat memperbaiki proses pembelajaran sehingga tujuan pembelajaran PBL dapat tercapai. Selain itu, siswa juga mempunyai target nilai yang ingin dicapai yang dituliskan pada penutup. Dengan target nilai tersebut diharapkan siswa lebih bersemangat dalam belajar agar target yang ditentukan dapat dicapai secara maksimal.

Jurnal tersebut kemudian diskor sesuai dengan rubrik penilaian yang tersedia. Penskoran dilakukan untuk mengetahui perkembangan siswa dalam menulis jurnal belajar. Skor rata-rata jurnal belajar siswa disajikan pada Gambar 2.

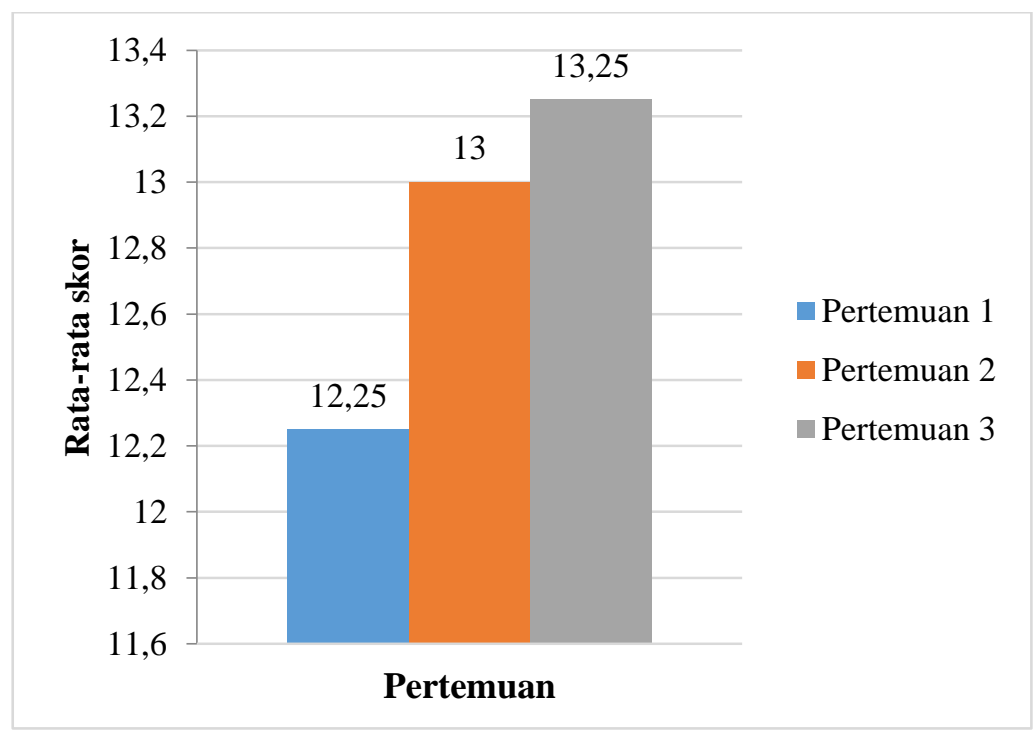

Gambar 2. Rata-rata skor jurnal belajar

Gambar 2 menunjukkan bahwa terjadi peningkatan skor rata-rata jurnal belajar karena adanya pembiasaan menulis jurnal belajar. Pada pertemuan pertama skor yang diperoleh paling rendah, kemudian mengalami kenaikan pada pertemuan kedua, dan pada pertemuan ketiga skor rata-rata meningkat dari pertemuan kedua dan telah terjadi pembiasaan. Sudrajat dalam Sayekti (2015) menyatakan bahwa kegiatan pembiasaan merupakan salah satu cara yang dapat digunakan untuk menumbuhkan karakter siswa. Lebih lanjut, karakter yang dimaksud meliputi rasa ingin tahu, terbuka, berpikir kritis, logis, kreatif, inovatif, jujur, disiplin, mandiri, bertanggung jawab, dan tidak mudah putus asa. Karakter yang dapat dikembangkan dalam penelitian ini adalah karakter berpikir kritis terkait dengan proses pemecahan masalah siswa. Karakter ini dapat dikembangkan karena pada pembelajaran dengan model PBL siswa dituntut untuk memecahkan masalah yang disajikan. Jariyah (2017) menyatakan bahwa berpikir kritis siswa dapat diperoleh melalui beberapa kegiatan, salah satunya adalah refleksi. Siswa dapat melakukan kegiatan refleksi diri melalui pembiasaan menulis jurnal belajar. 


\section{Model Problem Based Learning Berbantuan Jurnal Belajar terhadap Hasil Belajar Kognitif}

Data nilai akhir kelas kontrol dan eksperimen bersifat normal sehingga dapat dilakukan analisis selanjutnya untuk mengetahui pengaruh menggunakan statistik parametris. Hasil analisis korelasi pengaruh model problem-based learning berbantuan jurnal belajar terhadap hasil belajar kognitif siswa berdasarkan nilai akhir dapat dilihat pada Tabel 2.

Tabel 2. Hasil analisis korelasi

\begin{tabular}{lccccccl}
\multicolumn{1}{c}{ Jenis data } & $\mathbf{N}$ & $\mathbf{R}$ & $\mathbf{K D}(\boldsymbol{\%})$ & $\mathbf{D k}$ & $\mathbf{t}_{\text {tabel }}$ & $\mathbf{t}_{\text {hitung }}$ & Keterangan \\
\hline $\begin{array}{l}\text { Eksperimen } \\
\text { Kontrol }\end{array}$ & 22 & 0,78 & 61 & 20 & 2,02 & 9,067 & $\begin{array}{l}\text { Linear } \\
\text { Kuat }\end{array}$ \\
\hline
\end{tabular}

Nilai koefisien korelasi (r) 0,781. Koefisien korelasi tersebut digunakan untuk menguji hipotesis penelitian. Hasil analisis yang diperoleh untuk nilai $t_{\text {hitung }}=9,067>t_{\text {tabel }}=2,021$, yang menunjukkan bahwa hasil belajar kognitif berbeda secara signifikan terhadap hasil belajar kognitif siswa. Kontribusi pengaruh penugasan jurnal belajar dalam PBL terhadap hasil belajar kognitif adalah sebesar $r^{2}=61 \%$ yang tergolong dalam kategori pengaruh kuat, sehingga dapat dikatakan bahwa model PBL berbantuan jurnal belajar yang memberikan pengaruh kuat terhadap hasil belajar kognitif siswa selama kegiatan penelitian.

Hasil analisis data kelas eksperimen menunjukkan bahwa pemahaman konsep siswa yang diajar dengan penugasan jurnal belajar di dalam model PBL lebih baik daripada kelas kontrol yang diberi penugasan jurnal belajar tanpa menggunakan model PBL. Hal ini dapat dilihat pada pada saat pembelajaran menggunakan model PBL, siswa lebih tanggap dalam pertanyaan yang diajukan oleh guru. Hasil tersebut disebabkan karena selama proses pembelajaran, siswa kelas eksperimen diberi kesempatan untuk mengembangkan dirinya dengan memecahkan masalah melalui model PBL. Rusmono (2012) menerangkan bahwa model PBL mendorong siswa untuk mengorganisasikan masalah serta menganalisis dan mengevaluasi proses pemecahan masalah. Pada tahap mengorientasikan siswa pada masalah, pembelajaran dimulai dengan menyajikan masalah tentang gejala alam. Menurut Kusumaningtias et al. (2013) PBL sesuai dengan pembelajaran IPA karena berkaitan dengan lingkungan dan permasalahannya.

Tahap mengorganisasikan masalah, siswa terdorong untuk belajar, guru menarik siswa untuk lebih memperhatikan pelajaran. Pada tahap ini, guru membantu siswa untuk mengatur tugas-tugas yang berhubungan dengan masalah dengan membentuk kelompok untuk melakukan penyelidikan. Pemberian tugas memiliki tujuan memberi kesempatan kepada siswa untuk memupuk perkembangan, mengambil inisiatif, bertanggung jawab, dan mandiri (Sabriani, 2012).

Pada tahap membantu penyelidikan mandiri atau kelompok, siswa melakukan proses penyelidikan secara berkelompok dan mendiskusikan hasil yang diperoleh. Kegiatan diskusi terkait permasalahan kontekstual mampu mendorong siswa melakukan analisis dari pendapat tiap-tiap anggota kelompok. Melalui kegiatan diskusi, secara tidak langsung telah mengembangkan kemampuan berpikir kritis. Lebih lanjut, Surayya, Subagia, dan Tika (2014) menyatakan bahwa keterampilan berpikir kritis memengaruhi peningkatan hasil belajar 
kognitif. Selain itu, kegiatan diskusi yang dilakukan juga memudahkan siswa untuk mengingat materi, sehingga siswa tidak terpaku pada hafalan. Hal ini dijelaskan oleh (Sudesti, Fransisca, \& Mimin, 2014) bahwa pengalaman belajar dapat memudahkan siswa untuk mengingat dan memahami materi yang dipelajari.

Pada tahap mengembangkan dan mempresentasikan hasil karya, siswa melakukan kegiatan presentasi dan tanya jawab terkait hasil diskusi. Siswa diberi kesempatan oleh guru untuk maju ke depan kelas secara suka rela untuk mempresentasikan hasil. Kemudian, siswa yang lain mempersiapkan pertanyaan kepada kelompok yang maju. Tanya jawab yang dilakukan siswa terkait hasil penyelidikan menjadikan siswa lebih memahami materi pelajaran.

Pada tahap menganalisis dan mengevaluasi pemecahan masalah, peran guru adalah membantu siswa melakukan refleksi diri dengan memberikan tugas menulis jurnal belajar. Setiawan dan Susilo (2015) menyatakan bahwa dengan melakukan refleksi diri akan menjadikan seseorang berpikir secara mendalam terhadap kejadian atau pengetahuan yang diterima. Keterampilan seseorang dalam melakukan refleksi diri dapat mendorong kemempuan kognitif, metakognitif, perilaku belajar, dan hasil belajar (Herlianti et al., 2015).

Jurnal belajar yang digunakan pada penelitian ini adalah sebagai proses yang mendukung tercapainya tujuan pembelajaran di dalam model PBL. Kelas eksperimen dengan model PBL terlihat lebih antusias dalam mengikuti pelajaran. Pengamatan yang dilakukan selama proses KBM berlangsung, siswa kelas eksperimen lebih tanggap dalam menjawab pertanyaan yang diberikan oleh guru dibandingkan dengan siswa kelas kontrol. Dapat dikatakan siswa kelas eksperimen dengan model PBL memiliki minat belajar yang lebih tinggi dibandingkan siswa kelas kontrol. Fakta ini sesuai dengan Dwi, Arif, dan Sentot (2013) yang menyatakan bahwa model PBL menjadikan siswa termotivasi untuk menumbuhkan minat belajar siswa. Minat merupakan faktor yang menentukan tercapainya tujuan belajar, karena adanya minat belajar dalam diri siswa akan memudahkan guru untuk membimbing dan mengarahkan siswa.

Penggunaan jurnal belajar sebagai proses di dalam model PBL secara bersinergi mampu mendorong hasil belajar kognitif siswa. Jurnal belajar dijadikan sebagai alat untuk memonitoring tingkat kepahaman siswa (Fauziya \& Suhara, 2015). Guru mampu mengetahui perkembangan kognitif siswa selama belajar dengan menganalisis tiap kelemahan dan kelebihan yang dipaparkan siswa di dalam jurnal belajar.

Uji hipotesis dilakukan untuk mengetahui apakah jurnal belajar dalam pembelajaran berbasis masalah berpengaruh terhadap hasil belajar kognitif. Hasil analisis menunjukkan bahwa terdapat hubungan yang kuat antara jurnal belajar dalam PBL dengan hasil belajar kognitif siswa dengan besarnya pengaruh 61\%, sedangkan 39\% lainnya dipengaruhi oleh beberapa faktor. Abdullah (2012) menyatakan bahwa terdapat faktor eksternal dan faktor internal yang memengaruhi hasil belajar. Faktor eksternal yang dimaksud adalah keluarga, sekolah, dan masyarakat, sedangkan faktor internal yang dimaksud adalah jasmaniah, psikologis, dan kelelahan. Pada penelitian ini, faktor yang memengaruhi dari segi eksternal adalah dari guru. Peranan guru dalam mengelola waktu dan pengorganisasian kelas masih kurang, yaitu saat mengomunikasikan tujuan pembelajaran masih menggunakan bahasa yang 
bertele-tele. Selain itu apresiasi dan dorongan belajar kepada siswa masih kurang diberikan oleh guru.

\section{Model Problem-based Learning Berbantuan Jurnal Belajar terhadap Kemampuan Metakognitif}

Data nilai akhir tes kemampuan metakognitif kelas kontrol dan eksperimen bersifat normal sehingga dapat dilakukan analisis selanjutnya untuk mengetahui pengaruh menggunakan statistik parametris. Hasil analisis korelasi pengaruh model problem-based learning berbantuan jurnal belajar terhadap kemampuan metakognitif siswa berdasarkan nilai akhir dapat dilihat pada Tabel 3.

Tabel 3. Hasil analisis korelasi

\begin{tabular}{lccccccl}
\multicolumn{1}{c}{ Jenis data } & $\mathbf{N}$ & $\mathbf{R}$ & $\mathbf{K D}(\boldsymbol{\%})$ & $\mathbf{D k}$ & $\mathbf{t}_{\text {tabel }}$ & $\mathbf{t}_{\text {hitung }}$ & Keterangan \\
\hline Eksperimen & 22 & \multirow{2}{*}{0,639} & 41 & 20 & 2,021 & 6,667 & $\begin{array}{l}\text { Linear } \\
\text { Kontrol }\end{array}$ \\
\hline
\end{tabular}

Nilai koefisien korelasi (r) sebesar 0,639. Koefisien korelasi tersebut digunakan untuk menguji hipotesis penelitian. Hasil analisis yang diperoleh untuk nilai $t_{\text {hitung }}=6,667>t_{\text {tabel }}=$ 2,021, yang menunjukkan bahwa hasil belajar kognitif berbeda secara signifikan terhadap kemampuan metakognitif siswa. Kontribusi pengaruh penugasan jurnal belajar dalam PBL adalah sebesar $\mathrm{r}^{2}=41 \%$ yang tergolong dalam kategori pengaruh sedang, sehingga dapat dikatakan bahwa jurnal belajar dalam PBL yang memberikan pengaruh yang sedang terhadap kemampuan metakognitif siswa selama kegiatan penelitian.

Hasil tersebut sesuai dengan penelitian Setiawan dan Susilo (2015) bahwa penerapan jurnal belajar dan strategi PBL dipadu jigsaw yang dilakukan secara efektif melalui lesson study dapat meningkatkan keterampilan metakognitif. Selain itu, dalam penelitian Kusumaningtias et al. (2013) menyatakan bahwa PBL dipadu NHT mempengaruhi kemampuan metakognitif siswa dengan rata-rata nilai siswa lebih tinggi dari dibandingkan dengan kelas yang diajar secara konvensional. Penelitian Asiah, Sudarti, dan Lesmono (2016) juga menyatakan bahwa model PBL dengan teknik mind mapping berpengaruh terhadap hasil belajar dan sikap siswa yang menjadi lebih baik.

Hasil ini menunjukkan bahwa jurnal belajar dalam pembelajaran berbasis masalah memberikan pengaruh positif terhadap kemampuan metakognitif siswa. Handika dan Wangid (2013) menyatakan bahwa PBL memberikan peluang kepada siswa untuk lebih leluasa belajar secara mandiri, bertukar pikiran, dan membantu tugas kelompok. Senada dengan Handika \& Wangid (2013); Kusumaningtias et al., (2013) menyatakan bahwa PBL adalah model pembelajaran yang sesuai dengan IPA karena berkaitan dengan lingkungan dan permasalahannya. Sehingga, mampu meningkatkan kemampuan berpikir kritis siswa dalam memecahkan suatu masalah untuk memperoleh konsep dan kemampuan metakognitif.

Tujuan utama dari menulis jurnal belajar pada penelitian ini adalah untuk mengasah kemampuan kognitif dan metakognitif siswa. Pengetahuan metakognitf menurut Anderson dan Krathwohl (2001) adalah pengetahuan tentang kognisi yang mencakup pengetahuan strategis, tugas-tugas kognitif, dan pengetahuan diri. Siswa yang terbiasa menulis jurnal belajar semakin mengasah pengetahuannya perihal strategi-strategi belajar dan berpikir serta 
menyelesaikan masalahnya. Strategi yang diperoleh dapat digunakan untuk menyelesaikan tugas maupun mengerjakan soal. Selain itu, dengan mencantumkan daftar tugas di dalam jurnal belajar siswa memiliki kesadaran dengan tugas-tugas kognitif yang menjadi tanggung jawab mereka. Siswa yang diberi tugas menulis jurnal belajar dituntut untuk mempu menguraikan kelebihan dan kekurangan yang mereka miliki. Pengetahuan diri merupakan komponen penting dalam metakognisi karena penetahuan ini mencakup pengetahuan tentang kekuatan dan kelemahan diri sendiri dalam kaitannya dengan kognisi dan belajar.

Penilaian kemampuan metakognitif didasarkan pada beberapa aspek yang diadopsi dari Widadah et al. (2013), yaitu mengembangkan perencanaan, memonitor pelaksanaan, dan mengevaluasi tindakan. Siswa memiliki kemampuan mengembangkan perencanaan dengan baik yang dibuktikan dengan kemampuannya menuliskan komponen yang diketahui dan yang ditanyakan di dalam soal. Selain itu, siswa juga telah memiliki kemampuan dalam memonitor pelaksanaan. Hal ini ditunjukkan dengan siswa telah mampu menetapkan hasil dengan menyertakan strategi penyelesaian berupa langkah-langkah secara urut dan benar. Aspek yang terakhir yaitu mengevaluasi tindakan. Bagian akhir dari jawaban siswa menunjukkan bahwa siswa telah memiliki kemampuan mengevaluasi tindakan dengan menyertakan keyakinannya dalam menjawab soal disertai dengan alasan tertentu.

Uji hipotesis dilakukan untuk mengetahui apakah jurnal belajar dalam pembelajaran berbasis masalah berpengaruh terhadap kemampuan metakognitif. Hasil analisis menunjukkan bahwa terdapat hubungan yang sedang antara jurnal belajar dalam PBL dengan kemampuan metakognitif siswa dengan besarnya pengaruh 41\%. Sedangkan 59\% lainnya dipengaruhi oleh faktor lain. Peranan guru dalam mengelola waktu dan pengorganisasian kelas masih kurang, yaitu guru belum mampu mengondisikan kelas untuk tenang selama pembelajaran berlangsung. Hal ini tentunya mengganggu siswa lain yang bersungguh-sungguh memperhatikan. Selain itu, menulis jurnal merupakan kegiatan yang baru dilakukan oleh siswa yang menjadikan siswa kebingungan dalam menulis. Faktor lain yang memengaruhi adalah jawaban sebagian siswa yang tidak menuliskan langkah-langkah pengerjaan soal dengan tepat.

\section{SIMPULAN DAN SARAN}

\section{Simpulan}

Berdasarkan hasil penelitian yang telah dilakukan dapat disimpulkan bahwa jurnal belajar dalam pembelajaran berbasis masalah berpengaruh terhadap hasil belajar kognitif siswa dengan koefisien determinasi $61 \%$ yang berarti termasuk dalam kategori kuat. Jurnal belajar dalam pembelajaran berbasis masalah berpengaruh terhadap kemampuan metakognitif siswa dengan koefisien determinasi $41 \%$ yang berarti termasuk dalam kategori sedang. Dengan demikian, penggunaan jurnal belajar dapat digunakan guru untuk meningatkan kemampuan siswa.

\section{Saran}

Saran yang dapat direkomendasikan untuk menindaklanjuti penelitian ini yaitu masih diperlukan penelitian lebih lanjut mengenai pembelajaran dengan bantuan jurnal belajar siswa untuk mengetahui efektivitas penggunaan dari juranl belajar tersebut. 


\section{DAFTAR PUSTAKA}

Abdullah, R. (2012). Pembelajaran berbasis pemanfaatan sumber belajar. Jurnal Ilmiah DIDAKTIKA, 12(2), 216-231. https://doi.org/10.22373/jid.v12i2.449

Anderson, L. W., \& Krathwohl, D. R. (2001). A taxonomy for Learning, teaching, and assessing: A revision of Bloom's taxonomy of educational objectives. New York: Longman.

Arifin, Z. (2009). Evaluasi pembelajaran. Bandung: PT Remaja Rosdakarya.

Asiah, I. N., Sudarti, \& Lesmono, A. D. (2016). Pengaruh model problem based learning (PBL) dengan teknik mind mapping terhadap hasil belajar fisika Siswa di SMA negeri arjasa kelas X. Jurnal Pembelajaran Fisika, 4(4), 327-330. Retrieved from https://jurnal.unej.ac.id/index.php/JPF/article/view/3085

Black, S. A., \& Schwartz, A. J. (2015). Learning: Behavior grounded in experiences. Anesthesiology, 123(1), 10-11. https://doi.org/10.1097/ALN.0000000000000700

Dunlap, B. J. C. (2006). Using guided reflective journaling activities to capture students ' changing perceptions. TechTrends, 50(6), 20-26. Retrieved from https://eric.ed.gov/?id=EJ774643

Dwi, I. M., Arif, H., \& Sentot, K. (2013). Pengaruh strategi problem based learning berbasis ICT terhadap pemahaman konsep dan kemampuan pemecahan masalah fisika. Jurnal Pendidikan Fisika Indonesia, 9(5), 8-17. https://doi.org/10.15294/jpfi.v9i1.2575

Fauziya, D. S., \& Suhara, A. M. (2015). Evaluasi pembelajaran melalui penulisan jurnal reflektif berbasis penilaian diri di PBS. Indonesia STKIP Siliwangi. Jurnal Ilmiah UPT P2M STKIP Siliwangi, 2(1), 46-52. https://doi.org/10.22460/p2m.v2i1p46-52.163

Handika, I., \& Wangid, M. N. (2013). Pengaruh pembelajaran berbasis masalah terhadap penguasaan konsep dan keterampilan proses sains siswa kelas V. Jurnal Prima Edukasia, I(1), 85-93. https://doi.org/10.21831/jpe.v1i1.2320

Herlianti, P. S., Linuwih, S., \& Dwijananti, P. (2015). Independent learning strategy of natural science with "one day one diary for science" program. Jurnal Pendidikan Fisika Indonesia, 11(2), 148-155. https://doi.org/10.15294/jpfi

Iskandar, S. M. (2014). Pendekatan keterampilan metakognitif dalam pembelajaran sains di kelas. $\quad$ Erudio, 2(2), 13-20. Retrieved from https://erudio.ub.ac.id/index.php/erudio/article/view/151

Jariyah, I. A. (2017). Efektivitas pembelajaran inkuiri dipadu sains teknologi masyarakat (STM) untuk meningkatkan kemampuan berpikir kritis pada mata pelajaran IPA. JPBI (Jurnal Pendidikan Biologi Indonesia), 3(1), 1-9. https://doi.org/10.22219/jpbi.v3i1.3888

Kallio, H., Virta, K., \& Kallio, M. (2018). Modelling the components of metacognitive awareness. International Journal of Educational Psychology, 7(2), 94-122. https://doi.org/10.17583/ijep.2018.2789

Khusniati, M. (2012). Pendidikan karakter melaui pembelajaran IPA. Jurnal Pendidikan IPA Indonesia, 1(2), 204-210. https://doi.org/10.15294/jpii.v1i2.2140

Khusniati, M. (2014). Model pembelajaran sains berbasis kearifan lokal dalam menumbuhkan karakter konservasi. Indonesian Journal of Conservation, 3(1), 67-74. Retrieved from https://journal.unnes.ac.id/nju/index.php/ijc/article/view/3091 
Kissin, Y. V. (2013). Natural sciences: Definitions and attempt at classification. Cosmos and History: The Journal of Natural and Social Philosophy, 9(2), 116-137. Retrieved from https://www.cosmosandhistory.org/index.php/journal/article/view/372

Kusumaningtias, A., Zubaidah, S., \& Indriwati, S. E. (2013). Pengaruh problem based learning dipadu strategi numbered heads together terhadap kemampuan metakognitif, berpikir kritis , dan kognitif biologi. Jurnal Penelitian Kependidikan, 23(1), 33-47. Retrieved from https://www.researchgate.net/profile/Siti_Zubaidah5/publication/322467159_Pengaruh_ Problem_Based_Learning_Dipadu_Strategi_Numbered_Heads_Together/links/5a59fb4f 0f7e9b5fb38553cc/Pengaruh-Problem-Based-Learning-Dipadu-Strategi-NumberedHeads-Together.pdf/in

Lwin, M., Khoo, A., Lyen, K., Sim, C., Christine, S., \& Sugirin. (2008). Cara Mengembangkan Berbagai Komponen Kecerdasan. Yogyakarta: Indeks.

M. Huda. (2013). Model-Model Pengajaran \& Pembelajaran. Yogyakarta: Pustaka Belajar.

Masino, S., \& Niño-Zarazúa, M. (2016). What works to improve the quality of student learning in developing countries? International Journal of Educational Development, 48, 53-65. https://doi.org/10.1016/j.ijedudev.2015.11.012

Nurwahidah, I. (2017). Penggunaan asesmen pembelajaran IPA bagi siswa visual impairment di SLB Jawa Tengah. JIPVA (Jurnal Pendidikan IPA Veteran), 1(1), 39-50. Retrieved from http://e-journal.ivet.ac.id/index.php/jipva/article/view/517

Nurwahidah, I. (2018). Pengembangan soal penalaran model TIMSS untuk mengukur high order thinking (HOT). Thabiea: Journal of Natural ScienceTeaching, 1(1), 20-29. https://doi.org/10.21043/thabiea.v1i1.3874

Panchu, P., Bahuleyan, B., Seethalakshmi, K., \& Thomas, T. (2016). Metacognitive awareness- evaluation and implications in medical students. International Journal of Research in Medical Sciences, 4(8), 3570-3575. https://doi.org/10.18203/23206012.ijrms20162331

Prozesky, D. (2000). Teaching and learning. Community Eye Health, 13(34), 30-31.

Putri, R. S., \& Kurniati, D. (2015). Analisis keterampilan metakognitif siswa dalam menyelesaikan masalah matematika berbasis polya subpokok bahasan garis dan sudut kelas VII-C di SMP Negeri 1 Genteng Banyuwangi. Artikel Ilmiah Mahasiswa, 2(1), 1$7 . \quad$ Retrieved from http://repository.unej.ac.id/bitstream/handle/123456789/63775/RIANDANI SARWINDAH PUTRI.pdf? sequence $=1$

Rahayu, P., Mulyani, S., \& Miswadi, S. S. (2012). Pengembangan pembelajaran IPA terpadu dengan menggunakan model pembelajaran proble base melalui lesson study. Jurnal Pendidikan IPA Indonesia, 1(1), 63-70. https://doi.org/10.15294/jpii.v1i1.2017

Rifa'i, A., \& Anni, C. T. (2012). Psikologi Pendidikan. Semarang: Pusat Pengembangan MKU/MKDK-LP3 Unnes.

Rusmono. (2012). Strategi Pembelajaran dengan Problem Based Learning Itu Perlu. Bogor: Penerbit Ghalia Indonesia.

Sabriani, S. (2012). Penerapan pemberian tugas terstruktur disertai umpan balik pada pembelajaran langsung untuk meningkatkan motivasi dan hasil belajar siswa (studi pada materi pokok struktur atom kelas X6 SMA Negeri 3 Watampone). Jurnal Chemica, 


\section{3(2), 39-46. https://doi.org/10.26858/chemica.v13i2.625}

Sayekti, I. C. (2015). Peran pembelajaran IPA di sekolah dalam membangun karakter anak. In Prosiding Seminar Nasional dan Call for Papers (pp. 140-146). Retrieved from https://publikasiilmiah.ums.ac.id/handle/11617/6010

Setiawan, D., \& Susilo, H. (2015). Peningkatan keterampilan metakognitif mahasiswa program studi biologi melalui penerapan jurnal belajar dengan strategi jigsaw dipadu PBL berbasis lesson study pada mata kuliah biologi umum. In Prosiding Seminar Nasional Pendidikan Biologi (pp. 359-369). Retrieved from http://biology.umm.ac.id/files/file/359-369 Deny Setiawan .pdf

Siberman, M. L. (2014). Active Learning. Bandung: Nuansa Cendekia.

Skinner, A., Blum, N., \& Bourn, D. (2013). Development education and education in international development policy: Raising quality through critical pedagogy and global skills. International Development Policy, 4(3). https://doi.org/10.4000/poldev.1654

Sudarmin. (2015). Model Pembelajaran Inovatif Kreatif. Semarang: CV. Swadaya Manunggal.

Sudesti, R., Fransisca, S., \& Mimin, N. K. (2014). Penerapan pembelajaran berbasis praktikum untuk meningkatkan penguasaan konsep dan keterampilan proses sains siswa SMP pada subkonsep difusi dan osmosis. Formica Education Online, 1(1), 1-11. Retrieved from http://journal.fpmipa.upi.edu/index.php/feo/article/view/90

Surayya, L., Subagia, I. W., \& Tika, I. N. (2014). Pegaruh model pembelajaran think pair share terhadap hasil belajar IPA ditinjau dari keterampilan berpikir kritis siswa. Jurnal Pendidikan Dan Pembelajaran IPA Indonesia, 4(1), 1-11. Retrieved from http://oldpasca.undiksha.ac.id/e-journal/index.php/jurnal_ipa/article/view/1105

Susilo, A. B. (2012). Pengembangan model pembelajaran IPA berbasis masalah untuk meningkatkan motivasi belajar dan berpikir kritis siswa SMP. Journal of Primary Educational, $\quad 1(1), \quad 57-63 . \quad$ Retrieved from https://journal.unnes.ac.id/sju/index.php/jpe/article/view/58

Triana, E. (2012). Penerapan jurnal belajar terhadap peningkatan hasil belajar siswa pada konsep pencemaran dan kerusakan lingkungan. IAIN Syekh Nurjati Cirebon. Retrieved from http://repository.syekhnurjati.ac.id/443/1/ENDAH TRIANA_58461214_ok.pdf

Trianto. (2010). Model Pembelajaran Terpadu. Jakarta: Bumi Aksara.

Undang-undang. (2003). Sistem pendidikan nasional. Jakarta.

Wahdah, N. F., Jufri, A. W., \& Zulkifli, L. (2016). Jurnal belajar sebagai sarana pengembangan kemampuan metakognisi siswa. Jurnal Pijar MIPA, XI(1), 70-74. https://doi.org/10.14800/ics.95

Walker, C. L., \& Shore, B. M. (2015). Understanding classroom roles in inquiry education: Linking role theory and social constructivism to the concept of role diversification. SAGE Open. https://doi.org/10.1177/2158244015607584

White, N. M. (2011). Reward: What is it and how can it be inferred from behavior? In J. A. Gottfried (Ed.), Neurobiology of Sensation and Reward (pp. 45-60). Boca Raton (FL): CRC Press/Taylor \& Francis.

Widadah, S., Afifah, D. S. N., \& Suroto. (2013). Profil metakognitif siswa dalam menyelesaikan soal sistem persamaan linear dua variabel berdasarkan gaya kognitif. 
Jurnal Pendidikan Matematika STKIP PGRI Sidoarjo, 1(1), 13-24. Retrieved from https://www.researchgate.net/profile/Dian_Septi_Nur_Afifah/publication/318967128_P ROFIL_METAKOGNISI_SISWA_DALAM_MENYELESAIKAN_SOAL_SISTEM_P ERSAMAAN_LINEAR_DUA_VARIABEL_BERDASARKAN_GAYA_KOGNITIF_ METAKOGNISI\%27S_PROFILE_STUDENT_IN_SOLVE_EQUATION_SYSTEM_P ROB

Widiyawati, Y. (2017). Pemanfaatan media pembelajaran IPA bagi peserta didik visual impairment di SLB. JIPVA (Jurnal Pendidikan IPA Veteran), 1(1), 9-23. Retrieved from http://e-journal.ivet.ac.id/index.php/jipva/article/view/510

Zosh, J. M., Hopkins, E. J., Jensen, H., Liu, C., Neale, D., Pasek, K. H., ... Whitebread, D. (2017). Learning through play: A review of the evidence. Billund, Denmark: The LEGO Foundation. https://doi.org/10.13140/RG.2.2.11789.84963

\section{PROFIL SINGKAT}

Puji Lestari lahir di Wonogiri, 10 November 1995. Pendidikan terakhir di tempuh di Universitas Negeri Semarang (UNNES) pada Program Studi Pendidikan IPA dan diselesaikan pada tahun 2017. Saat ini bekerja sebagai staff pengajar di Lembaga Bimbingan Belajar Basmala Karanganyar.

Sri Wardani lahir di Pontianak, 8 November 1957 menempuh pendidikan sarjana di jurusan pendidikan kimia IKIP Semarang (sekarang menjadi UNNES) dan lulus pada tahun 1981. Tahun 1997 menempuh pendidikan S2 di Jurusan Kimia UNPAD dengan spesialisasi Kimia Analitik, dan lulus tahun 2001. Saat ini mengajar di jurusan Pendidikan Kimia UNNES mulai tahun 1983 hingga sekarang.

Miranti Kusniati lahir di Jepara, 16 November 1985 menempuh pendidikan S1 pada Program Studi Pendidikan Kimia di UNNES lulus tahun 2009 dan menempuh S2 Program Studi Pendidikan IPA lulus tahun 2011. Saat ini menjadi dosen di jurusan IPA Terpadu FMIPA UNNES sejak tahun 2012 hingga sekarang. 